\title{
Efficiency of Inoculation with Rhizobium in Peanuts (Arachis hypogaea L.) Grown in Brazilian Cerrado Soil
}

\author{
Salomão Lima Guimarães, Edna Maria Bonfim-Silva*, Analy Castilho Polizel de Souza, \\ Bency G. Simeon
}

Department of Agricultural and Environmental Engineering, Institute of Agricultural Sciences and Technology, Federal University of Mato Grosso, Rondonópolis, Brazil

Email: *embonfim@hotmail.com

How to cite this paper: Guimarães, S.L., Bonfim-Silva, E.M., de Souza, A.C.P. and Simeon, B.G. (2019) Efficiency of Inoculation with Rhizobium in Peanuts (Arachis hypogaea L.) Grown in Brazilian Cerrado Soil. Agricultural Sciences, 10, 948-956. https://doi.org/10.4236/as.2019.107072

Received: May 29, 2019

Accepted: July 20, 2019

Published: July 23, 2019

Copyright ( 2019 by author(s) and Scientific Research Publishing Inc. This work is licensed under the Creative Commons Attribution International License (CC BY 4.0).

http://creativecommons.org/licenses/by/4.0/

\begin{abstract}
In Brazil, the peanut culture has been expanding mainly in the state of São Paulo, responsible for $80 \%$ of the national production. It is an edible culture produces oil of excellent quality, contains proteins rich in amino acids that make up to $36 \%$ of weight of the grain. Furthermore, it is associated with nitrogen-fixing bacteria. However, the practice of inoculation is not very common in peanuts, being this species considered susceptible to nodularity with a large number of rhizobia. However, known's that inoculation with selected strains can increase the efficiency of symbiosis and peanut yield. Thus, the present study was proposed to evaluate the development of peanut inoculated with rhizobia and grown in Cerrado's Oxisol. The experiment was conducted in a greenhouse, in a completely randomized design, five treatments, one cultivar (IAC 505) and four replicates. The treatments were composed of three strains of rhizobia and two controls, one absolute and the other with nitrogen fertilizer $\left(50 \mathrm{mg} \cdot \mathrm{N} \cdot \mathrm{dm}^{3}\right)$. Each experimental plot has been consisted an $8 \mathrm{dm}^{3}$ pot with three plants. The inoculation was done, applying $3 \mathrm{~mL}$ of bacterial broth $\left(108 \mathrm{~mL}^{-1}\right.$ cells) in the root system of each plant. The SPAD index, number and dry weight of nodules, dry mass of shoots and roots, number and weight of grains were analyzed. The response of Peanuts inoculated was significantly, as all inoculated plants showed similar development to nitrogen-fertilized, emphasizing the potential for supplying nitrogen in peanut development.
\end{abstract}

\section{Keywords}

Biological Nitrogen Fixation, Nodulation, Symbiosis 


\section{Introduction}

The peanut is one of the world's most consumed oleaginous plants. In Brazil, it has distinguished itself by the ease of processing, the short cycle and the potential of the food industry. In addition, it has been grown in pasture and sugarcane plantations, and is also an alternative for agro forestry systems, crop rotation and winter crop, mainly in the northern and southern regions in the northeastern Brazil [1].

Like any crop of agricultural importance, peanut growth is influenced by nitrogen, which is considered one of the factors that limit the development of plants. Furthermore, nitrogen fertilizer directly contributes not only to yield but also to grain quality [2].

For completing the development, part of the nitrogen required by the peanut is obtained by symbiosis with bacteria rhizobia, the process called biological nitrogen fixation (BNF). These bacteria induce the plant nodulation and, when selected, may increase symbiotic efficiency by progressively increasing grain yield and nodulation [3].

The agricultural activity requires high degree of selection in the diversity of the population, seeking to increase the efficiency of the symbiotic nitrogen-fixing process [4].

In cereal production areas, particularly soybean, inoculation is essential for a yield high. For peanuts grown in Brazil, is still a low used practice. There is a large diversity of peanut rhizobia populations in tropical soils, which may difficult the inoculation success due to competition from native strains [5].

However, the importance of peanut inoculation in tropical regions may be adopted under conditions such as low population of native rhizobia, high temperatures, low soil moisture, or in those areas where the peanut or other legume was not grown. Due to the importance [3], of the BNF process for the sustainability of agricultural production, the objective of this present study had to evaluate the effect of the inoculation of native rhizobia strains on peanut cultivated in Cerrado's Oxisol.

\section{Methodology}

The experiment was conducted in a greenhouse at the Federal University of Mato Grosso, Rondonópolis-MT, with the geographic coordinates of $16^{\circ} 28^{\prime}$ South Latitude, $50^{\circ} 34^{\prime}$ West Longitude and $284 \mathrm{~m}$ altitude and Average rating = $30^{\circ} \mathrm{C}$ and $\mathrm{RU}=51 \%$.

The soil used in the experiment was Oxisol [6], collected in a Cerrado fragment, 0 to $20 \mathrm{~cm}$ depth and stored in pot with a capacity of $8 \mathrm{dm}^{3}$. The soil properties chemical analysis $\left(\mathrm{pH}\left(\mathrm{CaCl}_{2}\right)-4.2, \mathrm{P}-3.2 \mathrm{mg} \cdot \mathrm{dm}^{-3}, \mathrm{~K}-60 \mathrm{mg} \cdot \mathrm{dm}^{-3}\right.$, $\mathrm{Ca}-0.3 \mathrm{cmol}_{c} \cdot \mathrm{dm}^{-3}, \mathrm{Mg}-0.2 \mathrm{cmol}_{c} \cdot \mathrm{dm}^{-3}, \mathrm{Al}-1.0 \mathrm{cmol}_{c} \cdot \mathrm{dm}^{-3}, \mathrm{H}+\mathrm{Al}-6.1$ $\mathrm{cmol}_{\mathrm{c}} \cdot \mathrm{dm}^{-3}$, CTC-6.8, V (\%)-9.6), liming was realized with dolomitic limestone $80 \%$ PRNT, account for increasing saturation by $60 \%$, where it remained in incubation period for 30 days. 
During the merging between the limestone and the soil, moisture was maintained by the gravimetric method at $60 \%$ of the maximum water retention in the soil, determined in the laboratory according to the methodology described by [7].

After the incubation period, the fertilization was done with application of phosphorus, potassium and micronutrients. The phosphorus and potassium doses used were respectively 200 and $50 \mathrm{mg} \cdot \mathrm{dm}^{-3}$, the sources of which were simple superphosphate and potassium chloride.

The micronutrient fertilization was done with boric acid, copper chloride, zinc chloride and sodium molybdate at doses of $1.0 \mathrm{mg} \cdot \mathrm{dm}^{-3}, 1.0 \mathrm{mg} \cdot \mathrm{dm}^{-3}, 3,0$ $\mathrm{mg} \cdot \mathrm{dm}^{-3}$ and $0.2 \mathrm{mg} \cdot \mathrm{dm}^{-3}[7]$.

The experimental design was completely randomized with a peanut cultivar (IAC 505), this cultivar has a habit of low growth, indeterminate and vigorous plants. the cycle is from 130 to 140 days. Stands out for the stability of the production, presents excellent productive result in the average of several plantations

[8]. M. Presents an oil content in the grains varying between $49 \%-50 \%$ ), and its content of oleic acid is $70 \%$ to $80 \%$ [8].

With five treatments and four replications, making a total of 20 plots. The treatments were composed of three strains of rhizobia isolated from plants cowpea bean (MT8, MT15, and MT23) and two controls, the first with nitrogen fertilizer (50 $\mathrm{mg} \cdot \mathrm{dm}^{-3}$ with urea) and an absolute (without inoculation and nitrogen fertilizer).

The seeding was done at an average $2.5 \mathrm{~cm}$ depth, using 10 seeds per pot. After germination, the thinning was done, staying three plants per pot. The rhizobia strains were multiplied in the laboratory, in basis of the methodology proposed by [9].

The inoculation was done after the thinning of the plants, applying $3 \mathrm{~mL}$ of the bacterial broth composed of $108 \mathrm{CFU} \mathrm{mL} \mathrm{m}^{-1}$ near to the root system of each plant.

Were evaluated the variables SPAD index, dry mass of shoot and roots, number and dry mass of nodules, number's grains and grain yield.

The evaluation of the chlorophyll content was realized by the Clorofilog-1030 portable meter, performing a reading per plant. The roots of the plants were washed for soil removal, nodule extraction and counting. then, all the material was packed in paper bags, identified and submitted to drying in air oven with forced circulation with a temperature of $65^{\circ} \mathrm{C}$ for 72 hours or until the material reached a constant mass.

Statistical analysis was performed using the statistical program SISVAR 4.2 (Ferreira, 2011). Results were submitted to analysis of variance and the means of the treatments compared by the Tukey's test at $5 \%$ of probability [10].

\section{Results and Discussion}

The rhizobia inoculation strains on peanut plants results a significant effect on 
all variables evaluated.

\subsection{Chlorophyll Index}

The SPAD index is an indicator of the values that can be correlated with the chlorophyll content of the plants, which makes the assessment quick and convenient, due to the SPAD reading is directly related to plant nutritional status assessment, since there is a positive correlation between the leaf chlorophyll content and the $\mathrm{N}$ content in the plant and, consequently, crop yield [11].

This is due to the fact that $50 \%$ to $70 \%$ of the total leaf nitrogen is an enzyme component associated with chloroplasts [12].

In this study, the SPAD was evaluated 35 and 63 days after the seeding, as shown in Table 1. At 35 days, it was found that the highest value (44.1) was found for the treatment of plants had been inoculated with strain MT15, which was also higher to absolute control (37.7).

During the culture cycle (63 days), all strains showed good results, with SPAD index similar to those fertilized with nitrogen fertilizer (45.7) and with values higher than those observed in the absolute control. (38.8).

Reports in the literature discuss the importance of rhizobia in nitrogen supply for legume development.

[13] studied of the efficacy of rhizobia isolated from the soils of northeastern Brazil in the nitrogen-fixing in peanuts, showed that isolates S10, S11, A105 and A140 result an accumulation of Nitrogen in the shoot of peanut plants higher than that obtained with application of $100 \mathrm{mg} \cdot \mathrm{dm}^{-3}$ nitrogen, when the plants were grown in the soil of the Caatinga region and in the area with Mimosa caesalpiniaefolia.

[14] studied rhizobia inoculated in cowpea and verified that all the varieties studied showed an increase in accumulated nitrogen from biological fixation during the inoculation with strains BR 2001 and BR 3267.

Experiment realized had demonstrated that the peanut is a species that can establish symbiotic associations with native rhizobia, taking advantage of the

Table 1. SPAD index in peanut plants inoculated with rhizobia and grown in a Oxisol.

\begin{tabular}{ccc}
\hline & \multicolumn{2}{c}{ SPAD index } \\
\cline { 2 - 3 } Treatments & 35 DAS & 63 DAS \\
\hline MT08 & $40.4^{\mathrm{ab}}$ & $45.8^{\mathrm{a}}$ \\
MT15 & $44.1^{\mathrm{a}}$ & $43.0^{\mathrm{a}}$ \\
MT23 & $41.5^{\mathrm{ab}}$ & $42.5^{\mathrm{a}}$ \\
Nitrogen Control & $42.3^{\mathrm{ab}}$ & $45.7^{\mathrm{a}}$ \\
Absolute Control & $37.7^{\mathrm{b}}$ & $38.8^{\mathrm{b}}$ \\
CV (\%) & 6.1 & 10.6 \\
\hline
\end{tabular}

The averages followed by the same vertical letter do not differ from each other by the Tukey's test ( $\mathrm{p} \leq$ $0.05)$. 
interaction formed under conditions of low nitrogen availability in the soil, this response depends on the genotype of the plant.

These observations corroborate with the data obtained in this study, with the cultivar IAC 505 respond to the inoculation and the strains used proved to be competitive with the native rhizobia of the soil [3].

Differences were observed in dry shoot and root masses, with a positive effect of rhizobial symbiosis in peanut plants (Table 2).

\subsection{Dry Mass}

The shoot dry mass had a similar result among all strains, with equal increases for fertilized plants. In regard to roots, the highest values were obtained with MT15 treatments and the nitrogen control. Other treatments had similar values for this variable.

The increase in dry mass due to inoculation may be associated with the production of phytormones by bacteria such as auxins, gibberilins and cytokinins, which stimulate the formation of root hairs and secondary roots, resulting in higher water surface and nutrient absorption [15]. However, inoculation with mineral $\mathrm{N}$ supplementation can also increase dry mass yields compared to an isolated nitrogen supply [16].

In other legume producing crops, inoculation of selected rhizobia strains favored an increase in cowpea dry weight [17], common bean [18]. and pigeon bean [19], confirming the beneficial effects of legumes derived from symbiosis.

For different access to peanuts, [3] found that the dry mass of the roots varied with each access, confirming that the genotype has a direct influence on the association formed between the plant and the microorganism.

In the analysis of the number and dry mass of the nodules, was observed that there was significance between the treatments (Figure 1(a) and Figure 1(b)).

The treatment with Nitrogen control showed a higher number of nodules than rhizobial treatments. The literature mentions that mineral nitrogen may be have

Table 2. Dry shoot mass and roots of peanut inoculated with rhizobia and cultivated in Oxisol.

\begin{tabular}{ccc}
\hline & \multicolumn{2}{c}{ Dry mass $\left(\mathrm{g} \cdot \mathrm{pot}^{-1}\right)$} \\
\cline { 2 - 3 } Treatments & Shoot & Roots \\
\hline MT08 & $29.7^{\mathrm{a}}$ & $7.20^{\mathrm{ab}}$ \\
MT15 & $31.0^{\mathrm{a}}$ & $9.98^{\mathrm{a}}$ \\
MT23 & $29.1^{\mathrm{a}}$ & $8.67^{\mathrm{ab}}$ \\
Nitrogen Control & $36.1^{\mathrm{a}}$ & $9.91^{\mathrm{a}}$ \\
Absolute Control & $12.7^{\mathrm{b}}$ & $5.19^{\mathrm{b}}$ \\
CV (\%) & 21.2 & 19.6 \\
\hline
\end{tabular}

The averages followed by the same vertical letter do not differ among themselves by the Tukey's test ( $\mathrm{p} \leq$ $0.05)$. 


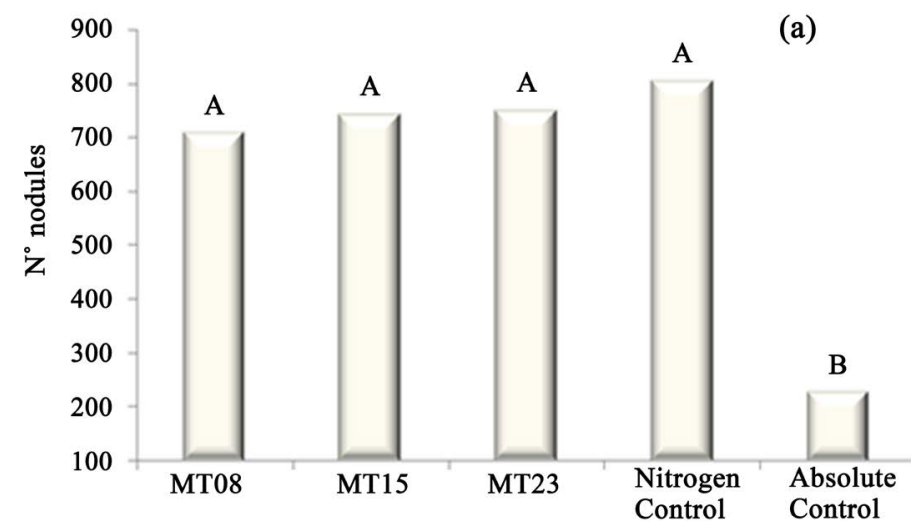

The averages followed by the same horizontal letter do not differ among themselves by the Tukey's test $(\mathrm{p} \leq 0.05)$.

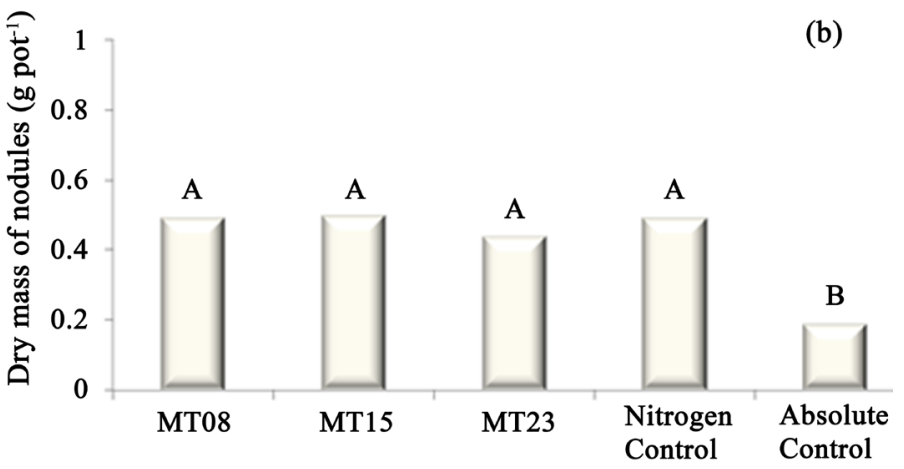

The averages followed by the same horizontal letter do not differ among themselves by the Tukey's test $(\mathrm{p} \leq 0.05)$.

Figure 1. Number (a) and dry mass of nodules (b) in peanut plants inoculated with rhizobia and cultivated in Oxisol.

an inhibitory effect on the biological nitrogen-fixing process, particularly when nitric and ammoniacal sources are applied. However, the nitrogen-fertilized plants in this study received urea as a nitrogen source, which has a less inhibitory effect on nodulation [20].

When evaluating the dry mass of Arachis pintoi nodules inoculated with rhizobia strains (BR-1432 and BR-1433), [17] verified that strains did not differ statistically, showing similarity between treatments, confirming values observed in this study, where absolute control exhibited lower averages than other treatments.

The low nodulation observed in the absolute control may be related to the low population of rhizobium in the soil, as well as the high number of rhizobial cells $\left(108 \mathrm{CFU} \cdot \mathrm{mL}^{-1}\right)$ used in inoculation treatments [13] [21].

The dry mass of the nodules showed a similar result that of the number of nodules, in which only the absolute control reached lower values, differently with the observations mentioned in the study of [22], the authors found no significant difference between inoculation treatments in number and in dry mass of nodules. However, the authors note that there is the effectiveness of the symbiosis, depending on the increases in the dry mass of peanut plants verified by 
Table 3. Number and dry weight of peanut inoculated and grown with rhizobia in dystrophic Red Oxisol.

\begin{tabular}{ccc}
\hline \multirow{2}{*}{ Treatments } & \multicolumn{2}{c}{ Grains } \\
\cline { 2 - 3 } & Number & Dry mass $\left(\mathrm{g} \cdot\right.$ pot $\left.^{-1}\right)$ \\
\hline MT8 & $58.25^{\mathrm{a}}$ & $24.58^{\mathrm{a}}$ \\
MT15 & $60.25^{\mathrm{a}}$ & $20.84^{\mathrm{a}}$ \\
MT23 & $51.00^{\mathrm{ab}}$ & $18.06^{\mathrm{a}}$ \\
Nitrogen control & $46.25^{\mathrm{ab}}$ & $17.18^{\mathrm{a}}$ \\
Absolute control & $26.75^{\mathrm{b}}$ & $3.46^{\mathrm{b}}$ \\
CV (\%) & 24.6 & 25.2 \\
\hline
\end{tabular}

The averages followed by the same vertical letter do not differ from each other by the Tukey's test ( $\mathrm{p} \leq$ $0.05)$.

rhizobia inoculation.

The peanuts crop, whether for in natura consumption or oil production, aims to obtain high yields. Although inoculation of rhizobium in groundnut is not yet widely practiced in Brazil, positive effects of this practice have been demonstrated both for the number and dry weight of beans (Table 3).

\subsection{Grains}

One of the reasons for the low use of rhizobia inoculated in peanut plants in Brazil is related to the ability of this crop to nodulate with several native rhizobia species [15], producing grains in quantities attend the basic needs of small farmers. However, the selection of efficient strains capable to increase the yield of legume, generating currency for the country [23]. The practice of rhizobia inoculated in legumes may increase the number of nodules, leading to increased productivity and reduced photosynthesis, reduce plant energy expenditure and potentially increasing yield [24].

\section{Conclusions}

Inoculation with the rhizobium strains yielded grain yields and yields for IAC 505 , demonstrating a favorable plant-bacterial interaction.

The MT08 and MT15 strains showed inoculant use potential in peanuts (Arachis hypogaea L.) cultured in Oxisol.

\section{Conflicts of Interest}

The authors declare no conflicts of interest regarding the publication of this paper.

\section{References}

[1] Bolonhezi, D., Mutton, M.Â. and Martins, A.L.M. (2007) Conservation Tillage to Peanut Crop in Rotation with Green Harvest Sugarcane. Pesquisa Agropecuária 
Brasileira, 42, 939-947. https://doi.org/10.1590/S0100-204X2007000700005

[2] Junior, A.F.C., de Oliveira, L.A. and de Oliviera, A.N. (2009) Indole-Acetic Acid Production by Rhizobia Isolated from Cowpea. Microbiology, 812-817.

[3] De Medeiros, E.V., Martins, C.M., Lima, J.A.M., Fernandes, Y.T.D., De Oliveira, V.R. and Borges, W.L. (2009) Morphological Diversity of Rhizobia from Cowpea Cultivated in Rio Grande Do Norte State Soils. Acta Scientiarum. Agronomy, 31, 529-535. https://doi.org/10.4025/actasciagron.v31i3.793

[4] Angelini, J., Ibáñez, F., Taurian, T., Tonelli, M.L., Valetti, L. and Fabra, A. (2011) A Study on the Prevalence of Bacteria that Occupy Nodules within Single Peanut Plants. Current Microbiology, 62, 1752-1759.

https://doi.org/10.1007/s00284-011-9924-2

[5] Fabra, A., et al. (2010) Interaction among Arachis hypogaea L. (Peanut) and Beneficial Soil Microorganisms: How Much Is It Known. Critical Reviews in Microbiology, 36, 179-194. https://doi.org/10.3109/10408410903584863

[6] Embrapa (2013) Brazilian Soil Classification System. 3rd Edition. Embrapa, Brasilia.

[7] Sousa, E. and Lobato, D.M.G (2002) Correction of Soil and Fertilization Planaltina. Embrapa Cerrados, Brasilia, 185-226.

[8] Godoy, L.K., Carvalho, I.J., Martins, C.L., Bolonhezi, A.L.M., Freitas, D., Kasai, R.S., Ticelli, F.S., Santos, M., Oliveira, J.F. and Morais, E.J. (2009) IAC 503 and IAC 505: Peanut Cultivars with the Characteristic "High Oleic". 5th Brazilian Congress on Plant Breeding, Guarapari.

[9] Hungria, M. and Nogueira (2014) Tecnologia de coinoculação: Rizobium e Azospirillum em soja e feijoeiro.

[10] Ferreira (2011) Sisvar: A Computer Statistical Analysis System. Ciencia e Agrotecnologia (UFLA), 35, 1039-1042. https://doi.org/10.1590/S1413-70542011000600001

[11] Smeal, D. and Zhang, H. (1994) Chlorophyll Meter Evaluation for Nitrogen Management in Corn. Communications in Soil Science and Plant Analysis, 25, 1495-1503. https://doi.org/10.1080/00103629409369130

[12] Chapman, S.C. and Barreto, H.J. (1997) Using a Chlorophyll Meter to Estimate Specific Leaf Nitrogen of Tropical Maize during Vegetative Growth. Agronomy Journal, 89, 557-562. https://doi.org/10.2134/agronj1997.00021962008900040004x

[13] Santos, C.E.R.S., et al. (2009) Effectiveness of Rhizobia Isolated from Soils of the Northeast Region of Brazil in the Fixation of N2 in Peanuts (Arachis hypogaea L.). Acta Scientiarum. Agronomy, 27, 301-307.

[14] Vieira, C.L., Freitas, A.D., Silva, A.F., Sampaio, E.V. and Araújo, M.S. (2011) Inoculation of Local Cowpea Varieties with Selected Rhizobia Strains. Revista Brasileira de Engenharia Agrícola e Ambiental, 14, 1170-1175. https://doi.org/10.1590/S1415-43662010001100006

[15] Santos Andrade, J.A., Viana, J.S., Cordeiro Junior, J.J.F., da Silva, A.C., Gonçalves, E.P. and Costa, D.S. (2015) Production of Peanut Intercropped with Forage Palm in Pernambuco State, Brazil. American Journal of Plant Sciences, 6, 818-825. https://doi.org/10.4236/ajps.2015.66088

[16] Ramos, A.S., Santos, T.M.C., Santana, T.M., et al. (2010) Action of Azospirillum lipoferum on the Development of Corn Plants. Revista Verde, 5, 113-117.

[17] Reis, V.R.R., Souza, L.R.S., Vieira, G.L.S., Coelho, K.B.S., Carmo Filho, A.D.S., and Silva, M.R.M. (2019) Vegetative Growth of Cowpea with Alternative Inoculant. 
Revista Verde de Agroecologia e Desenvolvimento Sustentável, 13, 466. https://doi.org/10.18378/rvads.v13i4.5630

[18] Veronezi, S.D.F., Costa, F.M., SIlva, M.R. and Mercante, A.T. (2012) Co-Inoculation of Rhizobium and Azospirillum brasilense in Common Bean (Phaseolus vulgaris L.). Cadernos de Agroecologia, 7, 1-5.

[19] Fernandes, M.F., Fernandes, R.P.M. and Hungria, M. (2003) Selection of Natives Rhizobia to the Cowpea, Pigeonpea and Jackbean Crops in the Coastal Tableland of Sergipe, Brazil. Pesquisa Agropecuária Brasileira, 38, 835-842. https://doi.org/10.1590/S0100-204X2003000700007

[20] Ruschel, A.P., Suhet, A.R., Vianni, D. and Almeida, L.R. (1975) Effect of Different Nitrogen Sources and Inoculation on Seed, Protein and Oil Production in Two Soybean Cultivars. Pesquisa Agropecuária Brasileira, 10, 19-23.

[21] Zilli, J.É., Gianluppi, V., Campo, R.J., Rouws, J.R.C. and Hungriin-Furrow, M. (2010) Inoculation with Bradyrhizobium Alternatively to Seed Inoculation of Soybeana. The Revista Brasileira de Ciência do Solo, 34, 1875-1881. https://doi.org/10.1590/S0100-06832010000600011

[22] Hoffman, L.V., Jacome, R.G. and Suassuna, T.M.F. (2007) Selection of Rhizobia Strains for Nodulation of Peanuts. Revista Brasileira de Oleaginosa e Fibrosa, 11, 107-111.

[23] Cavalcante, A., Cássio, A., Cavalcante, P., Guilherme, A., Alexandre, M. and Neto, D. (2016) Nitrogen-Fixing Bacteria and Organic Substrates on Growth and Chlorophyll Indices of Peanut. Agropecuária Técnica, 37, 1-8.

[24] Almeida, A.L.G., Alcântara, M.C.M., Nóbrega, A.L., Leite, S.A. and Silva, F.C. (2010) Productivity of Cowpea cv BR 17 Gurguéia Inoculated with Symbiotic Diazotrophic Bacterial in Piauí. Revista Brasileira de Ciências Agrárias, 5, 364-369. https://doi.org/10.5039/agraria.v5i3a795 